\title{
HLA AND MALARIA IN FOUR COLOMBIAN ETHNIC GROUPS (1)
}

\author{
Marcos ReSTREPO i2, Wibtiam ROJAS (2), fabiola MONTOYA (2),
} Astrid E. MONTOYA (2) d Deborah V. DAWSON (3)

\begin{abstract}
SUMMARY
HLA antigens and their relationship with malaria infection were studied in four different ethnic groups in Colombia (South America): two groups of indians (Kunas and Katios), one of negroes and a group of mixed ancestry. A total of 965 persons were studied, 415 with malaria and 550 as controls. HLA-A,B, and C antigen frequencies in the four groups are reported. The association of each HLA antigen with malaria infection due to $\mathbf{P}$. vivax and to $\mathbf{P}$. falciparum was evaluated. Negroes, Kunas and Katios indians variously lack from 6 to 9 of the HLA antigens found in the mixed group. In the designated ethnic groups, antigens B5, B13, B15, Cw2 and Cw4 showed borderline association with malaria infection. However, in the mixed ethnic group, statistically significant associations were found with malaria infection and the presence of A9, Aw19, B17, B35, and Z98 (a B21-B45: crossreacting determinant) with few differences when $\mathbf{P}$. vivax infection and $\mathbf{P}$. falciparum infection were considered individually. This finding may represent a lack of general resistance to malaria in the group that harbors antigens of Caucasian origin. These individuals have been in direct and permanent contact with malaria only in the past 65 years. In contrast, indians, both Kunas and Katios, and Negroes have lived for centuries in malaria endemic areas, and it is possible that a natural selection system has developed through which only those individuals able to initiate an acute immune response to malaria have survived.
\end{abstract}

KEY WORDS: HLA and Malaria

\section{INTRODUCTION}

The human leucocyte antigens (HLA) system includes genes (HLA-A, B, and C) which encode glycoproteins that are expressed on the surface of all nucleated cells and platelets of the individual. Experimental and epidemiological studies have established that the presence of some HLA antigens is associated with susceptibility to particular diseases or with the lack of immune responses to foreign antigens
(SVEJGAARD et al ${ }^{13}$ ). More than 40 diseases have been association with HLA antigens. The strongest association with HLA antigens. The strongest association so far established is between HLA-B27 and ankylosing spondylitis (SCHLOSSTEIN et al. 12). Individuals with this antigen run a risk of developing the disease that is 120 times greater than that of individuals lacking it; even so, $12 \%$ of the patients with

(1) Supported by Grants from Colciencias, FES and Fundación para el Desarrollo de la Ciencia y la Tecnología, Banco de la República (Colombia). Statistical analysis supported by USPHS Research Grant GM 10356.

(2) Corporación para Investigaciones Biológicas (CIB), Hospital Pablo Tobón Uribe, Apartado Aéreo 7378 Medellín, Colombia.

(3) Department of Microbiology and Immunology, Duke University Medical Center, Durham, NC, U.S.A.

Address for correspondence: Dr. Marcos Restrepo. Corporación para Investigaciones Biológicas (CIB), Hospital Pablo Tobón Uribe, Apartado Aéreo 7378 Medellin, Colombia. 
RESTREPO, M.: ROJAS, W.: MONTOYA, H, MONTOYA. A.E \& DAWSON, D.V. - HLA and maiaria in fou Colombian enhic groups. Kev. Inst. Med. trop. Säo Paulo, 3015):323-331, 1988

ankylosing spondylitis are B27 negative. Other imnortani association with specific HI.A antigens have been reported including some infectious diseases, as Yersinia, Chlamydia. shigella and Klebsiella (AHO el al.!, SAIRANEN \& TIILIKAINEN", EBRINGER (t al2).

PIAZZA et al.10, were among the first 10 investigate as associations between histocompatibility antigens and malaria. They suggested that differential selection, possibly linked to the immune response to malaria infection, might be responsible for variation they observed in the HL.A system. More recently, other investigators have reported HLA-associated antibody responses to malarial antigens and deviation in the frequency of certain HLA antigens among individuals with malaria (OSOBA et al". SY el al15.). In this study we looked into the possible correlations between HLA class 1 antigens and increased risk or resistance to infection with differen species of Plasmodium in foum difteren ethnic groups.

\section{MATERIALS AND MFTHODS}

\section{Study Populations}

The study population consisted of 415 persons with malaria, belonging to four differen ethnic group: Mixed, Kunas Indians, hatios Indians and Negroes. Random samples of each ethnic group totalizing 550 persons, were included in the studys as control populations. These control groups were formed by persons with no malaria at the time of the study. Although the occurrence of previous malaria infection can not be excluded, the possibility of their having had malaria is remote since the history was carefully taken and subjects of the study were persons that had lived in a malaria endemic area who are familiar with the sintomatology of the diseases and can therefore give reliable information. Besides, Hospital and SEM (Malaria Erradication Service) records were checked and it was found that none of them had consulted for malaria in the previous 5 years.

The people studied were inhabitants of four different areas in Colombia (See Map 1) as follows:

1. The Negro group. Descendants of West African Negroes, most of these people have lived in this area for centuries in isolation and it is assumed that there is a great degreee of genetic homogeneity among them; 98 individuals with malaria and 52 controls were included. The people of this group live in "El Valle", a town on the Pacific Ocean coast, in the State of Choco. The town has a population 2,500 and is located at sea level. Tropical forests surround the area and malaria is endemic.

2. Kuna Indians. This small group of 600 persons is composed of indians from the Chibcha family. Strong cultural patterns prevent marriage with individuals outside the Kuna communities of Colombia and Panama, making then a genetically homogeneous group. They live in Caiman Nuevo, and area located in the county of Turbo, north-west corner of the State of Antioquia. Malaria is endemic in the area; 23 indians with malaria and 81 controls were studied.

3. Katios Indians. The Katios belong to the Caribbean family and traditionally do not incrbreed with whites, mixeds, and blacks. In the past, however, they were warriors and it was their custom to taken women from other indians they conquered in war. Cienetically, they are free of contamination by non-indian races, but they may represent mixtures of different indian group belonging to the Caribbean, Chibcha and even Maya families. In the study 27 persons with malaria and 103 controls were included. These indians lived scattered along the east bank of the Atrato River in the State of Antioquia in an area where malaria is endemic. In contrast with the kunas, the Katios are semi-nomadic. Their settlements, composed of 50 to 150 persons each, are scattered throughout the jungle and can be reached only by helicopter.

4. The mixed group. A total of 267 persons with malaria and 314 as control were studied in the same village. These people lived in the Caucasia area, located in the low valley of the Cauca River in the State of Antioquia. Malaria is endemic in this region. Each member of this group represents a mixture of races: since colonial times the whites, Indians and Negroes area intermarried, and the products of this mix we call "mixed group". The occasional pure white, black or indian were excluded. 
RESTREPO, M.; ROJAS, W.; MONTOYA, F.; MONTOYA, A.E. \& DAWSON, D.V. - HLA and malaria in four Colombian ethnic groups. Rev. Inst. Med. trop. São Paulo, 30(5):323-331, 1988.

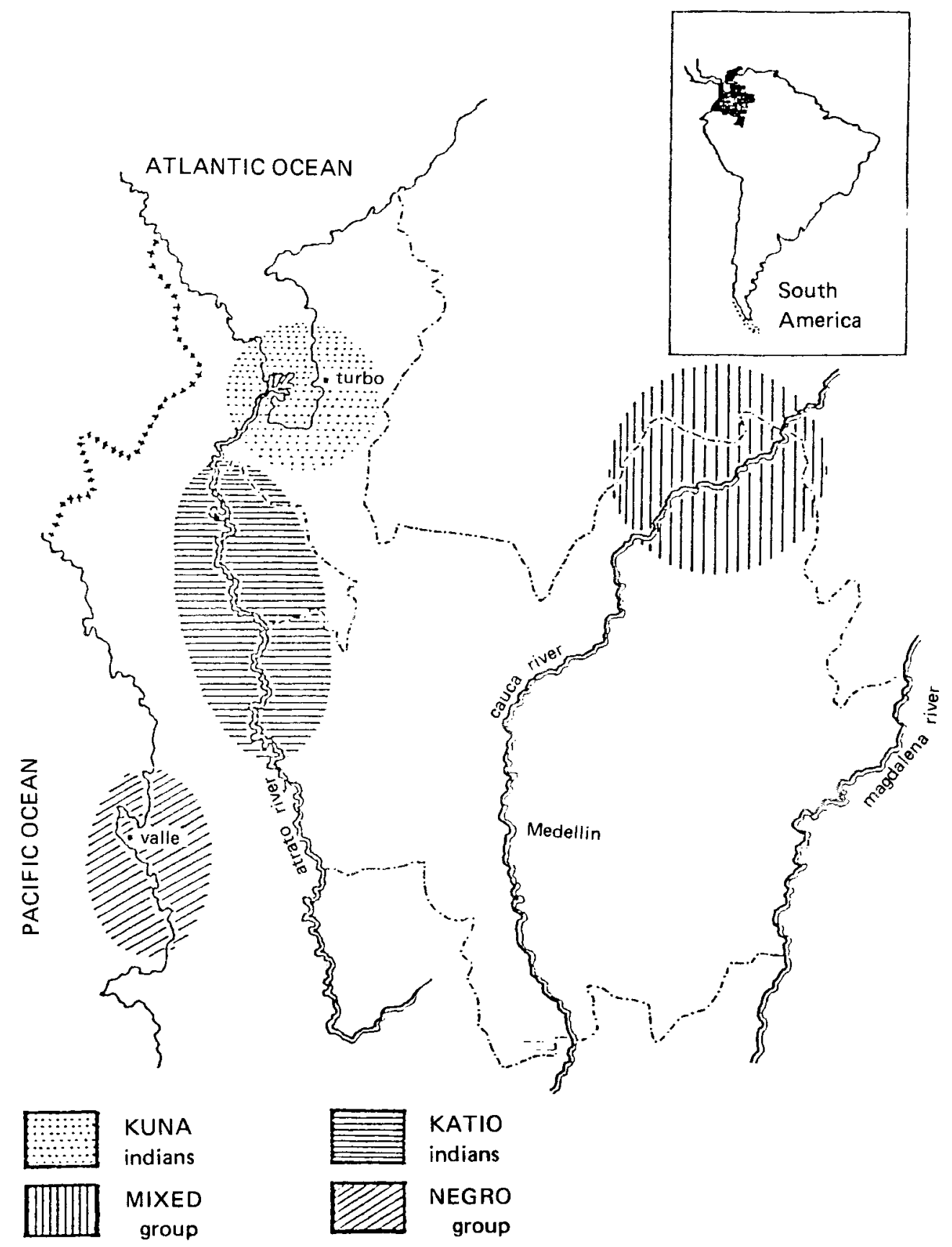

Map. 1. Distribution of ethnic groups in nort-west of Colombia. 
RESTREPO, M.; ROJAS, W.; MONTOYA, F.; MONTOYA, A.E. \& DAWSON, D.V. - HLA and malaria in four Colombian ethnic groups. Rev. Insi. Med. trop. São Paulo. 30(5):323-331, 1988.

\section{Laboratory Studies:}

Blood was taken from each of the 965 persons studied. Thick and thin smears werc prepared to be examined microscopically by and experienced technician after staining with Giemsa. Plasmodium species were recorded and the quantitative parasitic index determined.

An additional $6 \mathrm{ml}$ of blood was collected in a tube with $2 \mathrm{ml}$ of sodium citrate. Lymphocytes were separated by FicollHypaque. Viability of the cells was tested with trypan blue and the HLA antigen phenotype established by complement dependent cytotoxicity with the use of specific antisera. *The following antigens were studied: A1, A2, A3, A9, A10, A11, Aw19, A28, Aw36, B5, B7, B8, $\mathrm{B} 13, \mathrm{~B} 14, \mathrm{~B} 15, \mathrm{~B} 17, \mathrm{~B} 18, \mathrm{~B} 21, \mathrm{~B} w 22, \mathrm{~B} 27$, B35, B40, Bw53, Z98. (a B21-B45 determinamt); ( $w 2$ and $\mathrm{Cw} 4$.

\section{Statisticai Methods}

HI.A and Disease Association Studies. Possible associations between specificities of the HLA $A, B, C$, loci and the presence of discase were considered, where disease was variously defined as: a) history of malaria, b) presence of $\mathbf{P}$. falciparum, and c) presence of P. vivax.

We initially examined the similarity of within-locus HLA antigen frequencies between case and control populations using the omnibus test of Gart and Nam for each ethnic group studied (GART \& NAM ${ }^{4}$ ). Antigen frequency differences between disease and disease-free persons with respect to each of the particular HLA specificities studied were evaluated using Fischer's Exact Test (SVEJGAARD et al. ${ }^{14}$ ). Adjustments for multiple comparisons for each race-specific analysis were made using the standard Bonferroni methods (NETER \& WASSERMAN ${ }^{8}$ ). The odds ratio was estimated using Fleiss' modification (FLEISS ${ }^{3}$ ). The odds ratio serves as an index of association; if the risk of disease is small regardless of antigen status, then the odds ratio can also be viewed as an estimate of the relative risk. The statistical significance of this estimate relative to the hypothesis of no association is indicated by the same Fisher's Exact Test and p-value which evaluates the equivalency of antigen frequencies in cases and controls.

Population Studies of HLA in Normal Individuals. The antigenic distributions of the four ethnic groups were investigated by the estimation of antigen (phenotype) and gene (allele) frequencies and their standard errors according to the methods given by (MENDELL. \& WARD ${ }^{6}$ ). Pairwise comparisons of the HLA antigenic make-up of the ethnic groups were accomplished by use of the same techniques described in the previous section (omnibus test and Fisher's Exact Test with multiple comparisons adjustment).

Linkage disequilibrium for each of the twolocus haplotypes of the HLA-A, B and C antigens studied was also evaluated using Fisher's Exact Test. Although the data suggest that a number of the two-antigen combination examined may exhibit linkage disequilibrium. none of the two antigen associations with malaria were significant after adjustment for multiple comparisons.

\section{RESULTS}

\section{Number of cases with malaria, P. vivax and} $P$. falciparum infection

Table 1 presents the population distribution of patients with malaria and persons of the control groups. This table shows that the negroes had more $P$. falciparum infection $(92.9 \%)$ than P. vivax $(7.1 \%)$. P. falciparum in Kunas was $65.2 \%$ while P. vivax was seen more often in Mixed groups $(55 \%)$ and Katios $(63 \%)$. Table 2 shows age distribution of patients with infection by different species of Plasmodium. The incidence of malaria was high in the 20-49 years old persons, but the population was concentrated in this ages. No significant differences were found when Plasmodium species and age groups could were correlated.

\section{HLA in normal individuals (Table 3)}

As expected, not all HLA antigens which were tested were found in all four ethnic groups. Most of the antigens were present in the mixed group with only Z98 absent. Most

\footnotetext{
* Obtained from Behringgwerke AG., Marburg - Lahn, Germany.
} 
RESTREPO, M.; ROJAS, W.; MONTOYA, F.; MONTOYA, A.E. \& DAWSON, D.V. - HLA and malaria in four Colombian ethnic groups. Rev. Inst. Med. trop. São Paulo, 30(5):323-331, 1988.

TABLE 1

Population distribution of persons with and without malaria

\begin{tabular}{lrrrr}
\hline & P. falciparum & P. vivax & $\begin{array}{c}\text { Total } \\
\text { Infected }\end{array}$ & Control \\
\hline Mixed & 122 & 146 & $267^{*}$ & 314 \\
Katios & 11 & 17 & $27^{*}$ & 103 \\
Kunas & 15 & 9 & $23^{*}$ & 81 \\
Negroes & 91 & 7 & 98 & 52 \\
\hline & 239 & 179 & 415 & 550
\end{tabular}

* Includes one individual infected with both parasites.

TABLE 2

Distribution of the Plasmodium species according to age group

\begin{tabular}{cccccc}
$\begin{array}{l}\text { Age } \\
\text { groups }\end{array}$ & $\begin{array}{c}\text { P. vivax } \\
\mathrm{n}=176 \%\end{array}$ & $\begin{array}{c}\text { P. falciparum } \\
\mathrm{n}=236 \%\end{array}$ & $\begin{array}{c}\text { Total } \\
\mathrm{n}=412 \%(*)\end{array}$ \\
\hline $0-9$ & 11 & 37.9 & 18 & 62.1 & 29 \\
$10-19$ & 31 & 33.7 & 61 & 66.3 & 92 \\
$20-29$ & 57 & 45.6 & 68 & 54.4 & 125 \\
$30-39$ & 35 & 52.2 & 32 & 47.8 & 67 \\
$40-49$ & 22 & 44.9 & 27 & 55.1 & 45 \\
$50-59$ & 10 & 37.0 & 17 & 63.0 & 27 \\
$60-69$ & 5 & 31.3 & 11 & 68.7 & 16 \\
$70-79$ & 5 & 83.3 & 1 & 16.7 & 6 \\
$80-89$ & 0 & & & 100.0 & 1 \\
\hline
\end{tabular}

* Age groups porcentage

TABLE 3

Estimates of HLA-A,B and C Antigen Frequencies for Normal Controls Belonging to Four Colombian Ethnic Groups

Antigen (Phenotype) Frequencies (\%)

\begin{tabular}{|c|c|c|c|c|}
\hline $\begin{array}{c}\text { HLA } \\
\text { Antigen }\end{array}$ & $\begin{array}{c}\text { Mixed Group } \\
n=314\end{array}$ & $\begin{array}{c}\text { Katios Indians } \\
\mathbf{n}=103\end{array}$ & $\begin{array}{l}\text { Kunas Indians } \\
\qquad n=81\end{array}$ & $\begin{array}{c}\text { Negro Group } \\
\mathrm{n}=52\end{array}$ \\
\hline A1 & 22.3 & 6.8 & 3.7 & 7.7 \\
\hline A2 & 41.7 & 45.6 & 40.7 & 23.1 \\
\hline A3 & 14.0 & 2.9 & 3.7 & 19.2 \\
\hline A9 & 26.4 & 59.2 & 42.0 & 26.9 \\
\hline A 10 & 18.8 & 2.9 & 8.6 & 23.1 \\
\hline A11 & 11.5 & 6.8 & 0.0 & 7.7 \\
\hline Aw19 & 5.7 & 1.0 & 1.2 & 0.0 \\
\hline A 28 & 17.8 & 8.7 & 9.9 & 13.5 \\
\hline Aw36 & 0.6 & 0.0 & 0.0 & 1.9 \\
\hline B5 & 17.2 & 19.4 & 6.2 & $2 \star .2$ \\
\hline B7 & 14.0 & 2.9 & 1.2 & 13.5 \\
\hline B 8 & 8.9 & 0.0 & 0.0 & 7.7 \\
\hline $\mathrm{B} 12$ & 22.0 & .9 & 1.2 & 34.6 \\
\hline B 13 & 5.4 & 36 & 3.7 & 3.8 \\
\hline B 14 & 8.6 & 0.0 & 1.2 & 5.8 \\
\hline B 15 & 14.0 & 42.7 & 7.4 & 5.8 \\
\hline B 17 & 4.8 & 1.9 & 2.5 & 5.8 \\
\hline B 18 & 0.3 & 0.0 & 0.0 & 0.0 \\
\hline B 21 & 8.0 & 3.9 & 0.0 & 7.7 \\
\hline Bw 22 & 4.1 & 1.0 & 0.0 & 15.4 \\
\hline B 27 & 2.2 & 3.9 & 1.2 & 0.0 \\
\hline B35 & 34.9 & 41.7 & 54.3 & 25.0 \\
\hline B 37 & 1.9 & 0.0 & 0.0 & 1.9 \\
\hline B 40 & 15.9 & 26.2 & 46.9 & 15.4 \\
\hline Bw47 & 0.3 & 0.0 & 0.0 & 0.0 \\
\hline Bw53 & 0.3 & 0.0 & 0.0 & 0.0 \\
\hline Z98 & 0.0 & 2.9 & 2.5 & 0.0 \\
\hline Cw2 & 8.3 & 16.5 & 2.5 & 32.7 \\
\hline Cw4 & 35.0 & 31.1 & 53.1 & 25.0 \\
\hline
\end{tabular}

frequent antigens in the mixed group were: $\mathrm{A} 2$, A9; B35, B12; Cw4.

The indian and Negro groups were less polymorphic. Seven antigens were not found present in Katios: Aw36, B8, B14, B18, B37 and Bw47. The most commonly found antigens 
RESTREP(), M.; ROJAS, W.; MONTOYA, F.; MONTOYA, A.E. \& DAWSON, D.V. - HLA and malaria in four Colombian ethnic groups. Rev. Insi. Med. trop. São Paulo, 30(5):323-331, 1988

in this group were: A9, A2; B15, B35; Cw4. Nine antigens were absent in the Kunas: $A 11$, Aw36, B8, B18, B21, Bw22, B37, Bw47 and Bw53, while most common antigens were A9, A2; B35, B40; and Cw4. In the Negro group 6 antigens were absent: Aw19, B18, B27, Bw47, $B w 53$, and $Z 98$. The predominant antigens were A9, A10, A2; B12, B35; and Cw2.

\section{HLA and Malaria Association}

Comparisons between patients with malaria and control populations appear in Table 4 . In the mixed population, significant differences were found at the A and B loci when all patients with malaria were compared with controls and in $\mathbf{P}$. vivax patients vs. controls. In $\mathbf{P}$. falciparum infection, only the $B$ locus showed statistical differences. In the Katios, significant differences were observed only at the $C$ locus in patients with $\mathbf{P}$. vivax infection while in the Kuna group no significant difference was found in any comparison. In the Negro group significant differences at the $C$ locus were found between malaria patients and controls, and between individuals with $\mathbf{P}$. falciparum and controls.

If specific antigens rather than the indivi- dual loci are taken into consideration, several significant association are found after correction for multiple comparisons. In the mixed group, A9, B27, and B35 were significantly associated with malaria and $B 35$ with $P$. vivax (Table 5). Other associations were not significant after multiple comparison correction. The A9 and B27 associations imply and increased risk for malaria, while the $\mathrm{B} 35$ association implies resistance to the disease. This is reflected in the odds ratios. Other antigen associations (Aw 19, B17, and Z98) were statistically significant before but not after correction for multiple comparisons. In Katios, Kunas, and negroes no significant disease associations were observed after corrections for multiple comparisons. However, a slight decrease in the frequency of B 15 was found in Katios patients with malaria, of $\mathrm{B} 12$ and $\mathrm{Cw} 2$ in Negroes, and of B5 in P. vivax Kuna patients, possibly suggestive of an associated disease resistance. As shown in Table 6, among the antigens that were significantly different between the mixed patient and control groups, only A9 and Z98 were different between the mixed and both Indian control groups. Kuna and mixed control groups also differed in the frequency of $\mathrm{B} 35$.

TABLE 4

HLA-A, B and C Locus Antigen Frequency Differences between biseased and Malaria-Free Individuals of Four Ethnically-defined Colombian Populations:

HLA-Locus

\begin{tabular}{|c|c|c|c|c|c|c|c|c|c|c|}
\hline \multirow{2}{*}{$\begin{array}{l}\text { Racial } \\
\text { Group }\end{array}$} & \multirow[b]{2}{*}{ Comparison } & \multicolumn{3}{|c|}{ HLA-A } & \multicolumn{3}{|c|}{ HLA-B } & \multicolumn{3}{|c|}{$\mathrm{HLA}-\mathrm{C}$} \\
\hline & & $* * \mathrm{X}^{2}$ & $d f$ & $\mathrm{p}$ & $* * X^{2}$ & $\mathrm{df}$ & $\mathrm{p}$ & $* * \mathrm{X}^{2}$ & df & $\mathrm{p}$ \\
\hline \multirow[t]{3}{*}{ Katios } & Malaria present vs. controls & 9.79 & 8 & NS & 18.33 & 12 & NS & 3.47 & 2 & \\
\hline & P. falciparum present vs. controls & 8.71 & 8 & NS & 10.49 & 12 & NS & 0.49 & 2 & NS \\
\hline & P. vivax present vs. controls & 8.28 & 8 & NS & 19.91 & 12 & 0.069 & 6.57 & 2 & 0.037 \\
\hline \multirow[t]{3}{*}{ Kunas } & Malaria present vs. controls & 3.71 & 7 & NS & 10.77 & 11 & NS & 3.22 & 2 & NS \\
\hline & P. falciparum present vs. controls & 2.61 & 7 & NS & 9.72 & 11 & NS & 5.07 & 2 & 0.079 \\
\hline & P. vivax present vs. controls & 4.15 & 7 & NS & 18.08 & 11 & 0.080 & 0.78 & 2 & NS \\
\hline \multirow[t]{3}{*}{ Mixed } & Malaria present vs. controls & 30.50 & 9 & $3.6 \times 10$ & 70.90 & 18 & $4.4 \times 10$ & 0.89 & 2 & NS \\
\hline & P. falciparum present vs. controls & 15.39 & 9 & 0.081 & 43.20 & 18 & $7.5 \times 10$ & 1.71 & 2 & NS \\
\hline & P. vivax present vs. controls & 28.82 & 9 & $7.0 \times 10$ & 60.96 & 18 & $1.4 \times 10$ & 0.38 & 2 & $\mathrm{NS}$ \\
\hline \multirow[t]{3}{*}{ Negro } & Malaria present vs.controls & 10.95 & 9 & NS & 17.51 & 15 & NS & 9.13 & 2 & 0.010 \\
\hline & P. falciparum present vs. controls & 11.82 & 9 & NS & 18.06 & 15 & NS & 9.31 & 2 & 0.009 \\
\hline & P. vivax present vs. controls & 1.80 & 8 & NS & 14.55 & 13 & NS & 1.61 & 2 & NS \\
\hline
\end{tabular}

* Results of Gart and Nam's Within-Locus Omnibus Test

** Chi-square test statistics with associated degrees of freedom (df) and significance probabilities ( $p$ ), p-values denoted by "NS" were not significant at the 0.10 level of statistical significance. 
RESTREPO, M.; ROJAS, W.; MONTOYA, F.; MONTOYA, A.E. \& DAWSON, D.V. - HLA and malaria in four Colombian ethnic groups. Rev. Inst. Med. trop. Sāo Paulo, 30(5):323-331, 1988.

\section{TABLE 5}

Frequencies of HLA Antigens Found to Have Significant of Suggestive Associations with the Presence of Malaria in Four Ethnically-Defined Colombian Populations.

A. Associations with the presence of malaria of either type.

\begin{tabular}{|c|c|c|c|c|c|c|c|}
\hline $\begin{array}{l}\text { Ethnic } \\
\text { Groups }\end{array}$ & $\begin{array}{l}\text { Number } \\
\text { Cases }\end{array}$ & $\begin{array}{l}\text { Studied } \\
\text { Controls }\end{array}$ & $\begin{array}{c}\text { HLA } \\
\text { Antigen }\end{array}$ & $\begin{array}{c}\text { Frequency }(\%) \\
\text { Patients }\end{array}$ & $\begin{array}{c}\text { Frequency }(\%) \\
\text { Controls }\end{array}$ & $\mathrm{p}^{*}$ & $\begin{array}{l}\text { Odds } \\
\text { Ratic }\end{array}$ \\
\hline \multirow[t]{6}{*}{ Mixed } & 267 & 314 & A9 & 44.9 & 26.4 & $5 \times 10^{-6}$ & 2.3 \\
\hline & & & Aw19 & 2.3 & 5.7 & 0.0250 & 0.4 \\
\hline & & & B 17 & 12.0 & 4.8 & 0.0021 & 2.7 \\
\hline & & & B27 & 9.0 & 2.2 & 0.0003 & 4.1 \\
\hline & & & B35 & 20.6 & 34.4 & 0.0003 & 0.5 \\
\hline & & & 298 & 1.9 & 0.0 & 0.0201 & 13.2 \\
\hline Katjos & 27 & 103 & B15 & 18.5 & 42.7 & 0.0254 & 0.3 \\
\hline Negro & 98 & 52 & $B 12$ & 17.4 & 34.6 & 0.0250 & 0.4 \\
\hline
\end{tabular}

B. Associations with the presence of Plasmodium falciparum

\begin{tabular}{|c|c|c|c|c|c|c|c|}
\hline $\begin{array}{l}\text { Ethnic } \\
\text { Groups }\end{array}$ & $\begin{array}{l}\text { Number } \\
\text { Cases }\end{array}$ & $\begin{array}{l}\text { Studied } \\
\text { Controls }\end{array}$ & $\begin{array}{l}\text { HLA } \\
\text { Antigen }\end{array}$ & $\begin{array}{l}\text { Antigen } \\
\text { Cases }\end{array}$ & $\begin{array}{l}\text { Frequency }(\%) \\
\quad \text { Controls }\end{array}$ & $\mathrm{p}^{*}$ & $\begin{array}{l}\text { Odds } \\
\text { Ratio }\end{array}$ \\
\hline Mixed & 122 & 314 & $\begin{array}{l}\text { A9 } \\
\text { B17 } \\
\text { B27 } \\
\text { B35 }\end{array}$ & $\begin{array}{r}41.8 \\
12.0 \\
8.2 \\
23.0\end{array}$ & $\begin{array}{r}26.4 \\
4.8 \\
2.2 \\
34.4\end{array}$ & $\begin{array}{l}0.0026 \\
0.0174 \\
0.0098 \\
0.0215\end{array}$ & $\begin{array}{l}2.0 \\
2.6 \\
3.0 \\
0.6\end{array}$ \\
\hline Negro & 91 & 52 & $\begin{array}{l}\mathrm{B} 12 \\
\mathrm{C} w 2\end{array}$ & $\begin{array}{l}17.6 \\
13.2\end{array}$ & $\begin{array}{l}34.6 \\
32.7\end{array}$ & $\begin{array}{l}0.0257 \\
0.0087\end{array}$ & $\begin{array}{l}0.4 \\
0.3\end{array}$ \\
\hline
\end{tabular}

\begin{tabular}{|c|c|c|c|c|c|c|c|}
\hline $\begin{array}{l}\text { Ethnic } \\
\text { Groups }\end{array}$ & $\begin{array}{c}\text { Number } \\
\text { Cases }\end{array}$ & $\begin{array}{l}\text { Studied } \\
\text { Controls }\end{array}$ & $\begin{array}{c}\text { HLA } \\
\text { Antigen }\end{array}$ & $\begin{array}{c}\text { Antigen } \\
\text { Cases }\end{array}$ & $\begin{array}{l}\text { Frequenc } \\
\text { Controls }\end{array}$ & $\mathrm{p}^{*}$ & $\begin{array}{l}\text { Odds } \\
\text { Ratio }\end{array}$ \\
\hline Mixed & 146 & 314 & $\begin{array}{l}\text { A9 } \\
\text { B } 17 \\
\text { B27 } \\
\text { B35 } \\
\text { Z98 }\end{array}$ & $\begin{array}{r}48.0 \\
13.0 \\
9.6 \\
18.5 \\
2.7\end{array}$ & $\begin{array}{r}26.4 \\
4.8 \\
2.2 \\
34.4 \\
0.0\end{array}$ & $\begin{array}{c}10^{-5} \\
0.0034 \\
0.0010 \\
0.0004 \\
0.0099\end{array}$ & $\begin{array}{r}2.6 \\
3.0 \\
4.5 \\
0.4 \\
19.9\end{array}$ \\
\hline $\begin{array}{l}\text { Katios } \\
\text { Kunas }\end{array}$ & $\begin{array}{r}17 \\
9\end{array}$ & $\begin{array}{r}103 \\
81\end{array}$ & $\begin{array}{l}\text { Cw4 } \\
\text { B5 }\end{array}$ & $\begin{array}{r}5.9 \\
44.4\end{array}$ & $\begin{array}{r}31.1 \\
6.2\end{array}$ & $\begin{array}{l}0.0385 \\
0.0049\end{array}$ & $\begin{array}{r}0.2 \\
11.4\end{array}$ \\
\hline
\end{tabular}

* Significance probabilities (p-value) refer to the test of the hypothesis that case and control frequencies of a given HLA antigen are equal, using Fisher's Exact Test. Starred p-values denote a difference in antigen frequency which is statistically significant at an overall 0.05 level after adjustment for multiple comparison made for the 29 antigenic specificitics. Other quoted- $p$-values are not significant at the 0.05 level after multiple comparisons adjustment, but may be regarded as suggestive.

\section{DISCUSSION}

Several antigens of the HLA system which were found in the mixed populations are absent in the Negro and Indian groups (Kunas and Katios). Limited polymorphism has been reported by other investigators for other Amerindians and work carried out in our laboratory in other Colombian Indian groups shows similar findings (KOSTYU \& AMOS 5 ,
MONTOYA et al. ${ }^{7}$ ). It is possible that fewer HLA antigens are present in our indians and blacks because of inbreeding, but they may have other HLA antigens not yet detected or identified since the estimate of blank alleles (assuming random mating) is rather high. It is possible that contact with malaria during centuries, or millenia, has resulted in natural selection taking place in ethnic groups that been living in malaria endemic areas. If this is the 
RESTREPO, M.; ROJAS, W.; MONTOYA, F.; MONTOYA, A.E. \& DAWSON, D.V. - HLA and malaria in four Colombian ethnic groups. Rev. Inst. Med. trop. São Paulo, 30(5):323-331, 1988.

TABLE 6

Conarisons of HLA Antigen frequencies in nomals of the Mixed ethnic group with normal population frequencies in three other Colombian ethnic groups*

\begin{tabular}{lccc} 
HLA Antigen & Katios Indians & Kunas Indians & Negroes \\
A $9 * *$ & $5 \times 10$ & 0.00917 & NS \\
Aw19 & NS & NS & NS \\
B17 & NS & NS & NS \\
B27** & NS & NS & NS \\
B 35** & NS & 0.00132 & NS \\
298 & 0.01474 & 0.04164 & NS \\
\hline
\end{tabular}

* Antigens considered were those for which suggestive or statintically significant associations with malaria found among Mixed group individuals studied. Significance probabilities $(p)$ for wise comparisons, refer to Fisher's Exact Test of the hypothesis that a specific HLA antigen frequency did not differ for the two groups compared. P-values indicated by "NS" not rigniticant at the $5 \%$ level of statistical significance.

* * Indicates significant malarial association after adjustment for multiple comparisons.

case, those individuals with the inherited capability of establishing a good response against Plasmodium infection have been able to survive. Kunas and Katios have inhabited malaria endemic areas for many centuries and the blacks that inhabit the Pacific Coast of Colombia (an endemic area) have ancestors from the low lands of West Africa, were they have been continously exposed to plasmodia infection for centuries.

The mixed group in this study shows the most interesting findings. Several HLA antigens show a significant association with malaria infection. One of these antigens, B17, was reported by PIAZZA to be less frequent in persons from Sardinia where their ancestors had been exposed to malaria for centuries (PIAZZA et al.10.). He interpreted this finding as representing evolutionary selections. Although other antigens, A9, B27 and B35, were more closely associated with the infections, approximately $4.8 \%$ of the control population of our mixed group had B17 while it was present with a frequency of $12.0 \%$ in individuals with malaria, implying that individuals with this antigen are genetically more susceptible to the Plasmodia infection. Individuals from the mixed group are descendents of people who have living in the Taraza area, a malaria endemic section, only since 1920 . Before this, the area was a jungle with no white or mixed population, and only a few Indians lived there. Colonization of the area by mixed individuals started only at the begining of this century by people who previosly lived above 1.500 meters over sea level where malaria was not present. Presumably natural selection for resistance to malaria, if it occurs, has not yet taken place in this mixed group.

\section{RESUMO}

HLA e malária em quatro diferentes grupos étnicos da Colômbia

Foram estudados os antígenos HLA e a relação destes com a infecção malárica em 4 diferentes grupos étnicos da Colômbia (América do Sul); dois grupos de índios (Kunas e Katios), um grupo de negros e um grupo que apresentava ancestrais mistos. Foram estudadas 965 pessoas, das quais $415 \mathrm{com}$ malária e 550 como controles. A frequência dos antígenos HLA-A, $\mathrm{B}$ e $\mathrm{C}$ foram determinados nos quatro grupos estudados. A associação de cada antígeno HLA com a infecção por P. vivax e P. falciparum foi avaliada. Os antígenos HLA 6-9 encontrados no grupo de ancestrais mistos, de um modo geral não foram observados nos grupos de negros e índios (Kunas e Katios). Nos grupos étnicos mencionados, os antígenos B5, B13, B15, Cw2 e Cw4 apresentaram uma associação limitrofe com a infecção por malária. Entretanto, no grupo étnico de ancestrais mistos foi observada uma associação estatísticamente significativa com a infecção malárica, sendo que a presença de A9, Aw 19, B17, B35 e Z98 (B21-B45: determinantes de reação cruzada) mostrou poucas diferenças quando as infecções por P. vivax e P. falciparum foram consideradas individualmente. Esse achado pode representar, de um modo geral, uma falta de resistência a malária no grupo portador de antígenos de origem caucasiana, os quais tem tido um contacto direto e permanente com a malária somente nos últimos 65 anos. Em contraste, os índios (Kunas e $\mathrm{Ka}$ tios) e os negros tem vivido durante séculos em áreas endêmicas para malária, é possível que um sistema de seleção natural tenha sido desenvolvido permitindo que somente aqueles indivíduos capazes de iniciar uma resposta imune à malária sobrevivam. 


\section{ACKNOWLEDGEMENTS}

We want to express our special recognition to: Drs. Bernard Amos and Frances Ward from the Dept. of Microbiology and Immunology, Duke University for their assistance and advice; Patrulla Aérea Colombiana and Mauricio Echavarría, medical student and pilot, that took us many times to the remote areas where part of the study was carried out.

\section{REFERENCES}

1. AHO, K.: AHVONEN, P.: LASSUS, A.: SIEVERS, K. \& TIILIKAINEN, A. - HL-A27 in reactive arthritis: a study of Yersinia arthritis and Reiter's disease. Arthr. and Rheum., 17:520, 1974.

2. EBRINGER, A.; BAINES, M.\& PTASZYNSKA, T. -Spondyloarthritis, Uveitis, HLA-B27 and Klebsiella. Immun. Rev., 86:101-116, 1985.

3. FLEISS, J.L. - Statistical methods for rates and proportions. New York, John Wiley, 1973

4. GART, J.J. \& NAM, J. - Statistical methods for genetic studies of HLA and cancer. In: CORNEI.L, R.G., ed. - Statistical methods for cancer studies. New York. Marcell Dekker, 1984, p.229-266.

5. KOSTYL, D.D. \& AMOS, D.B. - Mysteries of the Amerindians. Tissue Antigens, 16:111-123, 1981.

6. MENDELL, N.R. \& MARD, F.E. - Statistical methods in human genetics and immunology. In: INGRAM, D. \& BLOCK, R.F., ed. - Mathematical methods in medicine. New York, John Wiley, 1984. p. 162-216

7. MONTOYA, F.; ROJAS, W.; RESTREPO, M. \& MONTOYA, A.E. - Presencia de HLA en 3 comunidades indigenas de Colombia. (Unpublished paper)

8. NETER, J. \& WASSERMAN, W. - Applied linear statistical models. Homewood City, Illinois, Richard D. Irwin, Inc., 1974

9. OSOBA, D.; DICK, H.M.; VOLLER, A.; GOOSEN, T.J.; GOOSEN, T.; DRAPER C.C.\& THE, G. - Role of the HLA complex in the antibody response to malaria under natural conditions. Immunogenetics, 8:323-338, 1979.

10. PIAZZA, A.; BELVEDERE, M.C.; BERNOCO, D.; CONIGHI, C.; CONTU, L.; CURTONI, E.S.; MATTIUZ, P.L; MAYR, W; RICHIARDI, P.; SCUDELLER, G. \& CEPPELLINI, R. - HL-A variation in four sardinian villages under differential selective pressure by malaria. In: DAUSSET, J. \& COLOMBANI, J., ed. - Histocompatibility testing (1972). Copenhagen, Munksgaard, 1972. p.73-84.

11. SAIRANEN, E. \& TIILIKAINEN, A. - HLA B27 in Reiter's disease following shigellosis. Scand. J. rheumat., (suppl. 8): abstract 30, 1975.

12. SCHLOSSTEIN, L.: TERASAKI, P.1.; BLUESTONE, R. \& PEARSON, C.M. - High association of an HLA antigen, Bw-27 with ankylosing spondylitis. New Engl. J. Med., 288:704-706, 1978.

13. SVEJGAARD, A.; PLATZ, P.; RYDER, L.P.; NIELSEN, L.S. \& THOMSEN, M. - HL-A and disease associations. A survey. Transplant. Rev., 22:I-43, 1975

14. SVEJGAARD, A.; HAUGE, M.; JERSILD, $C$. PLATZ, P.; RYDER, L.P.; STAUB-NIELSEN, L. \& THOMSEN, M. - The HLA system. An introductory survey. $2^{\text {ndid. }}$ rev. ed. Basel, Karger, 1979. (Monographs in Human Genetics, vol. 7).

15. SY, N.E.; LONG, G.W.; ALCANTARA, A.K. RANOA, C.P. \& CROSS, J.H. - HLA antigens and malaria at a San Lazaro Hospital, Manila, Phillipines. Southeast Asian J. trop. Publ. Hith., 15:1-16, 1984.

Recebido para publicação em 19/9/1987. 